\title{
Impact of Service Quality on Customer Satisfaction: A Study Based on Bingiriya Divisional Secretariat
}

\author{
A.H.M.D.H. Abeysinghe ${ }^{1} \&$ T.K. Karandakatiya ${ }^{2}$ \\ ${ }^{1,2}$ Department of Business Management \\ Faculty of Business Studies \& Finance \\ Wayamba University of Sri Lanka \\ Kuliyapitiya \\ SRI LANKA \\ diliniabeysinghe15@gmail.com ${ }^{1}, \underline{\text { thusithakk@wyb.ac.lk }{ }^{2}}$
}

\begin{abstract}
Divisional secretariats are important public institutions in Sri Lanka that provide various public services. Service quality of divisional secretariats is very sensitive to the public that come to receive various services from them and most of time public has unfavorable response towards the service of those divisional secretariats. The divisional secretariat of Bingiriya also has the same issue. Therefore, it is vital for divisional secretariat of Bingiriya to know its service quality from the consumers' perspective in order to better understand their needs and hence satisfy them. Consequently, the main purpose of this study was to evaluate the dimensions of service quality of the services provided by the Bingiriya divisional secretariat and its impact on customer satisfaction. A research model was developed by investigating the previous literature in order to assess the impact of service quality dimensions on customer satisfaction. The quantitative research approach was applied in the study. Data was collected from a sample of 306 customers of Bingiriya division following convenience sampling method in order to assess their expectations and perceptions of service quality and the public satisfaction through structured questionnaire. The model consists of five dimensions such as tangibility, reliability, responsiveness assurance and empathy. The model was tested using the statistical tool of regression analysis. Data analysis revealed that only tangible, reliability, responsiveness, and empathy have a significant impact on customer satisfaction where reliability is the most influential dimension and empathy is the second dimension. Assurance dimension was unable to indicate impact on customer satisfaction in Bingiriya divisional secretariat.
\end{abstract}

Keywords: Customer Satisfaction, Government Services, Service Quality,

\section{INTRODUCTION}

\subsection{Problem}

Divisional secretariats have huge responsibility in dealing with citizens as it is the administrative level of the central government which is closer to the general public. Customers have a common desire for personalized and close relationship with service providers. It has become increasingly important for divisional secretariats' vision to conceptualize the service 
concept beyond the short-term goals to the long-term national values.

The divisional Secretariats have been established to serve the public through the decisions and policies of the government. Where, serving to the satisfaction of general public is the major concern. The Bingiriya divisional secretariat has employed various methods to measure the satisfaction level and the service quality through introducing

suggestion box, appoint an officer to the "customer complaints" subject, obtaining written information (by a form) and so on. However, it can be seen the customer satisfaction level is generally low than expected (Table 2), and also customer complaints increase year by year (Table 1 ).

Table 1. Customer Complaints: Divisional Secretariat, Bingiriya

\begin{tabular}{|c|c|} 
Year & Customer complaints \\
\hline $\mathbf{2 0 1 6}$ & $32 \%$ \\
\hline $\mathbf{2 0 1 7}$ & $41 \%$ \\
\hline $\mathbf{2 0 1 8}$ & $48 \%$ \\
\hline $\mathbf{2 0 1 9}$ & $51 \%$ \\
\hline
\end{tabular}

Source: Annual Report (2019)

Table 2. Customer Satisfaction Divisional Secretariat, Bingiriya

\begin{tabular}{l|c} 
Section & $\begin{array}{c}\text { Satisfaction level of } \\
\text { the customers }\end{array}$ \\
\hline Admin & $60 \%$ \\
\hline Land & $40 \%$ \\
\hline Development & $68 \%$ \\
\hline Social Service & $52 \%$ \\
\hline Samurdhi & $70 \%$ \\
\hline Accounts & $75 \%$ \\
\hline
\end{tabular}

Source: Annual Report (2019)
Though the Bingiriya Divisional Secretariat has taken several measures to address the customer satisfaction related issues, there is an inadequacy of proper investigation on how its service quality affect on the customer satisfaction. Therefore, the aim of this study is to investigate the impact of service quality on customer satisfaction of Bingiriya Divisional Secretariat.

\subsection{Objectives of the Research}

1. To measure the current level of service quality of the Bingiriya Divisional Secretariat.

2. To evaluate the impact of service quality of the Bingiriya Divisional Secretariat on customer satisfaction.

3. To identify what extent each service quality dimensions influence on customer satisfaction level.

\subsection{Previous Work}

When review the literature on the impact of service quality on customer satisfaction in government sector, the researcher identified several important evidences according to the previous researches. Parasuraman et al., (1991) suggested that when perceived service quality is high, then it will lead to increase in customer satisfaction.

According to the previous researchers, tangibility, reliability, responsiveness, assurance and empathy can be identified as the major dimensions of the service quality (Parasuraman et al., 1991). The SERVQUAL model describes the five variables as follows. Tangibles includes the physical 
evidence of the service, physical facilities, appearance of personnel, tools or equipment used to provide the service, physical representations of the service such as a plastic credit card or bank statement, other customers in the service facilities. Reliability refers to as the firm performs the services right the first time and honors its promises. It involves in accuracy in keeping records correctly, performing the service at the designated time (Parasuraman et al, 1985). Parasuraman et al (1985) and Zeithaml et al (2006) have given the definition of responsibilities as it concerns the willingness or readiness of employees to provide service. One of the aspects in the assurance factor is "knowledge to answers questions." Assurance is a knowledge and courtesy of employees and ability to inspire trust and confidence (Parasuraman et al 1985). SERVQUAL described empathy as "caring, individual attention the firm provides to customers" (Parasuraman et al., 1988; Zeithaml et al 2006: Sureshchandar et al., 2002).

\subsection{Research Gap}

After carefully analyzing various research studies conducted so far using the SERVQUAL model, it has been realized that many research work have been carried out in different service industries such as education, restaurants, banking, and health care. However, limited empirical studies have been conducted using the SERVQUAL model to assess service quality and its impact on customer satisfaction in divisional secretariats including Bingiriya divisional secretariat. Therefore it is evident that there is an empirical research gap in pertinent with the said area. Therefore, the purpose of this study is to analyzing the impact of service quality on customer satisfaction of Bingiriya divisional secretariat.

\subsection{Research Model and Hypotheses Development}

In line with the literature, a research model was developed establishing the relationships between service quality and customer satisfaction. Further, relationships were established between each service quality dimension and customer satisfaction (Cronin \& Taylor, 1992, Butcher, 2001, Ndubisi, 2006, Bitner, 1990, Caruana,et al,2000). Resultant hypotheses are given below.

$\mathrm{H}_{1}$ : There is a significant impact of tangibility on customer satisfaction.

$\mathrm{H}_{2}$ : There is a significant impact of reliability on customer satisfaction.

$\mathrm{H}_{3}$ : There is a significant impact of responsiveness on customer satisfaction.

$\mathrm{H}_{4}$ : There is a significant impact of assurance on customer satisfaction.

$\mathrm{H}_{5}$ : There is a significant impact of empathy on customer satisfaction.

\section{METHOD}

\subsection{Research Approach}

Researcher applied deductive approach in this study, which is concerned with developing hypotheses based on existing theory, 
and then designing a research strategy to test the hypotheses. In this study researcher has found the theory from the previous literature and hypotheses have been developed accordingly. Then researcher collected the data from the sample and made conclusions.

\subsection{Population}

Population of this study is the customer of divisional secretariat in 3 months in 2019 and it amount to 2000 customers.

\subsection{Sample}

In this study, sample is consisting with conveniently selected people who came to the divisional secretariat within the duration of 3 months in 2019.The convenience sampling method was used in this study since the names of the customers who came to get the service are not recorded in one place and which prevents from using a probability sampling technique due to the absence of a sampling framework.

A sample of 322 customers was selected according to the 'Morgan's Table' (Krejcie \& Morgan, 1970). There are 6 main divisions in the divisional secretariat which provide services. Therefore, a sample was taken from customers who came to those divisions to get services. When selecting respondents from selected divisions, 54 customers were chosen from 4 divisions and 53 customers were chosen from 2 divisions by giving equal chance to those divisions. It is practically impossible to find respondents from each and every division.
Following table shows how the sample is selected from population.

Table 3. Illustration of the Sample Selection

\begin{tabular}{|c|c|c|}
\hline Section & $\begin{array}{c}\text { No of } \\
\text { Customers }\end{array}$ & $\begin{array}{l}\text { Sample } \\
\text { Size }\end{array}$ \\
\hline 1-Land & 54 & \multirow{6}{*}{322} \\
\hline 2-Admin & 54 & \\
\hline 3-Development & 54 & \\
\hline 4-Account & 54 & \\
\hline 5-Social & 53 & \\
\hline 6- Samurdhi & 53 & \\
\hline
\end{tabular}

Sources: Survey data

\subsection{Data Collection and Analysis}

\subsubsection{Data Collection}

Primary data was used to gather information on both service quality and customer satisfaction. Data was collected through a questionnaire from a selected sample. Questionnaire was developed in order to disclose key indicators which are related to independent and dependent variables to achieve research objectives. Established research instruments were used to measure the variables (Parasuraman, 1988., Olorunniwo, 2006). Secondary data was collected in many ways such as, internet, newspapers, research articles and magazine. Mainly secondary data collected from customer complaints and subject officer's reports.

\subsubsection{Data Analysis}

The present study utilized both descriptive and inferential statistical techniques for data analysis. Descriptive statistics involved central tendency (mean) and measures of 
dispersion (variance, standard deviation, skewness). Inferential statistics were included multiple linear regression and correlation coefficient to test the hypotheses.

\section{RESULTS}

\subsection{Reliability of the Instrument}

Before analyzing the data, reliability test was performed to identify the reliability of each instrument which was used to measure the research variables.

Cronbach's Alpha values for each independent variable (tangibility, reliability, responsiveness, assurance and empathy) and dependent variable (customer satisfaction) were greater than 0.7 (Table 4).

Table 4. Cronbach's Alpha for independent variables and dependent variable

\begin{tabular}{|l|c|c|}
\hline \multicolumn{1}{|c|}{ Variable } & $\begin{array}{c}\text { No } \\
\text { of } \\
\text { items }\end{array}$ & $\begin{array}{c}\text { Cronbach's } \\
\text { Alpha } \\
\text { value }\end{array}$ \\
\hline Tangibility & 06 & 0.895 \\
\hline Reliability & 05 & 0.853 \\
\hline Responsiveness & 04 & 0.832 \\
\hline Assurance & 04 & 0.861 \\
\hline Empathy & 04 & 0.776 \\
\hline $\begin{array}{l}\text { Customer } \\
\text { Satisfaction }\end{array}$ & 08 & 0.910 \\
\hline
\end{tabular}

Source: Survey Data

\subsection{Hypotheses Testing}

In this research study, five hypotheses were developed as stated above and they were tested by using the Pearson
Correlation Coefficient (r) and regression analysis. Summary of results is indicated in table 5 .

According to the results of Pearson correlation analysis, correlation coefficient value of tangibility is $0.676^{* *}(\mathrm{p}<0.05)$ Hence; tangibility significantly and positively related to the customer satisfaction. According to the regression analysis result, $\mathrm{B}$ value of tangibility is 0.167 and it is significant $\quad(p<0.05) . \quad$ It means tangibility significantly affects the customer satisfaction. Hence, hypothesis one is accepted.

Reliability correlation coefficient value is $0.747^{* *}(\mathrm{p}<0.05)$. Hence, reliability is signific- antly and positively related to customer satisfaction. According to the regression analysis result, $\mathrm{B}$ value is 0.377 and it was significant $(\mathrm{P}<0.05)$. It means reliability significantly affects the customer satisfaction. Hence hypothesis two is accepted.

Responsiveness correlation coefficient value is $0.709^{*} *(\mathrm{p}<0.05)$. Hence, responsiveness significantly and positively related to the customer satisfaction. According to the regression analysis result, $\mathrm{B}$ value is 0.141 and it is significant $(p<0.05)$. It means responsiveness significantly affect the customer satisfaction. Hence hypothesis three is accepted.

Assurance correlation coefficient value is $0.669 * *(\mathrm{p}<0.05)$. Therefore, it is significantly related to the customer satisfaction. According to the regression analysis result, $\mathrm{B}$ value is -0.048 significant value of assurance is 0.508 . Its value is greater than 0.05. It means assurance is not 
significantly affecting the customer satisfaction. Hence, hypothesis four is not accepted.

According to the results of correlation analysis, correlation coefficient value of empathy is $0.685^{* *}(\mathrm{P}<0.05)$. Therefore, it is significantly and positively related to the customer satisfaction. According to the regression analysis result, $\mathrm{B}$ value is 0.206 it is significant $(\mathrm{P}<0.05)$. It means empathy significantly affects the customer satisfaction. Hence, hypothesis five is accepted.

\section{Table 5. Coefficients Table - Backward step multiple regression model}

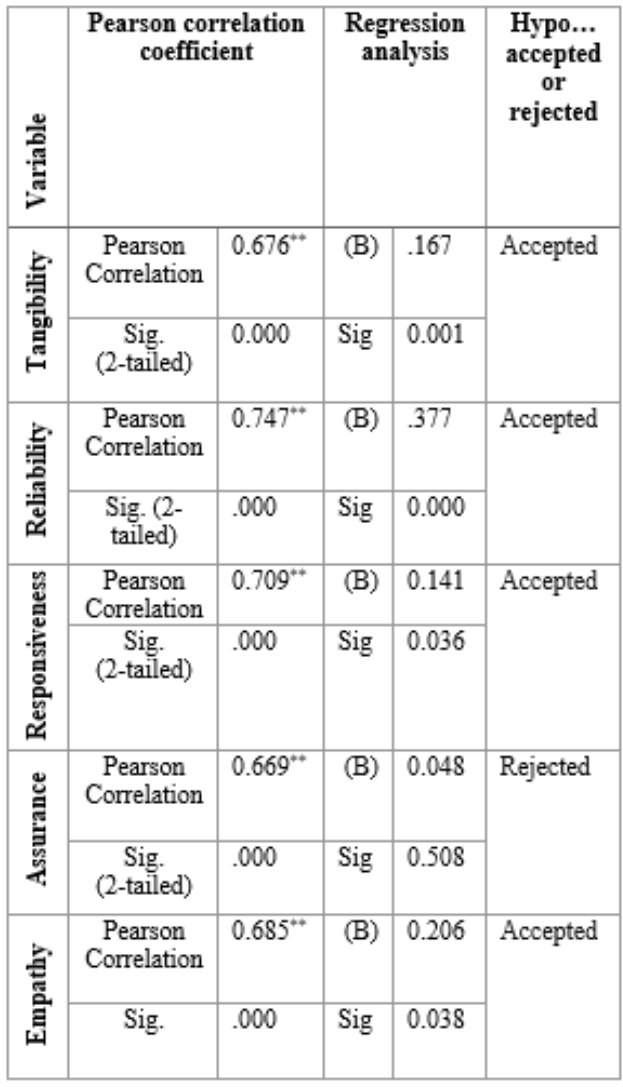

Sources: Survey Data

\section{DISCUSSION}

\subsection{Findings}

This research is conducted to identify the impact of service quality dimension on customer satisfaction with special reference to Bingiriya divisional secretariat. Study showed that service quality dimensions impact on customer satisfaction in different ways. Correlation coefficient and regression analysis were used to identify the relationship between service quality and customer satisfaction and the impact of service quality dimensions on customer satisfaction. According to Pearson correlation analysis, strong positive significant relationship between service quality and customer satisfaction can be identified as pvalue is less than 0.05 level. Further, there is a significant positive relationship between tangibility and customer satisfaction, reliability and customer satisfaction, responsiveness and customer satisfaction, assurance and customer satisfaction and empathy and customer satisfaction. It can be clearly stated there is a strong association between service quality dimensions and the customer satisfaction with respect to the Bingiriya divisional secretariat. Those findings are substantiated by several previous research findings (Rod, 2009; Wang \& Shieh, 2006; Marković \& Janković, 2013).

Most influential service quality dimension that influence on customer satisfaction can be identified through multiple regression analysis that is calculated through stepwise. The stepwise multiple regression analysis gives the sense to conclude that 
customer satisfaction is influenced by the factors of service quality dimensions such as tangible, reliability, responsiveness, and empathy in the Bingiriya divisional secretariat. Finally, the results of this study conclude that reliability can be identified as most critical factor of service quality dimension towards customer satisfaction in Bingiriya divisional secretariat where it has highest contribution towards customer satisfaction when compared with other service quality dimensions. Empathy shows as the next most influential dimension on customer satisfaction in Bingiriya division. However, the service quality dimension of assurance did not indicate significant impact on customer satisfaction in Bingiriya division. As per the previous research, such results may be available due to various reasons and that should be further investigated (Zaim, Bayyurt, \& Zaim, 2010).

\subsection{Significance, Limitations and Suggestions}

The present study indicates that by handling the service quality dimensions, specifically, the Bingiriya and other divisional secretariats can develop their strategies to improve the satisfaction of publics those who are coming to obtain various services from them. Further, the present study suggests for policy and decision makers of public service in Sri Lanka to consider the difference of importance of service quality dimensions from customer point of view in trying to enhance the service quality as their importance is not alike. Further, future researchers in this line can extend the present study by avoiding the following limitations.

The present study has several delimitations. It focuses only on the customer satisfaction and the service quality dimension. Accordingly, further research could investigate with more details the service quality dimension and their influence on customer satisfaction. Furthermore, future studies could focus on the dimension of assurance and could examine how the assurance dimensions could drive the satisfaction of customer.

The present research focused only on customer satisfaction in Bingiriya division, so future researches can focus the customer satisfaction in other divisional secretariats as well. Further, alternative data collection techniques can be considered in future studies as respondents indicated hesitation to disclose accurate information, some customers refused to participate in the survey.

\section{CONCLUSION}

This research is conducted to identify the impact of service quality on customer satisfaction in Bingiriya division. This study further shows that only four service quality dimensions (Tangible, Reliability, Responsiveness, and Empathy) having an impact on customer satisfaction. Those most influential dimensions will lead to have a higher customer satisfaction. The assurance is the dimension which has no impact on customer satisfaction in Bingiriya divisional secretariat. However, the results of this study can be used for 
service quality improvements, strategy innovations and consequently improving customer satisfaction of Bingiriya division specifically.

\section{REFERENCES}

Annual Report (2019), Divisional Secretariat, Bingiriya.

Bitner, M. J. (1990). Evaluating service encounters the effects of physical surroundings and employee responses. Journal of Marketing, 52(2).pp. 69-82.

Butcher, K. (2001). Evaluative and relational influences on service loyalty. International Journal of Service Industry Management, 12(4), pp.310-327.

Caruana, A., Money, A.H. and Berthon, P.R. (2000). Service quality and satisfaction- the moderating role of value. European Journal of Marketing, 34(11/12), pp.1338-1352.

Cronin,J.J.,7 Taylor,S. (1992). Measuring Service Quality - A Reexamination And Extension.Journal of Marketing. 56.pp.55-68.

Krejcie,R., $\&$ Morgan,D.(1970).Determinig sample size for research activities. Educational and Psychological Measurement.30.pp.607-610.

Marković, S. \& Janković,S.R. (2013). Explo- ring the relationship between service quality and customer satisfaction in Croatian hotel industry. Tourism 19( 2).pp.149-164.
Ndubisi, N. O. (2006). A structural equation modeling of the antecedents of relationship quality in the Malaysia banking sector. Journal of Financial Services Marketing, 11(2).pp. 131-141.

Olorunniwo,F.O.,\&Hsu,M.K(2006).A typolog- $y$ analysis of service quality, customer satisfy- action and behavioral intentions in mass services. Journal of Service Theory and Practice. 16(2).pp.106-123.

Parasuraman, A., Zeithaml, V., and Berry, L.L. (1985). A conceptual model of service quality and its implications for future research. Journal of Marketing,49(4). pp.41-50.

Parasuraman, A., Zeithaml, V., and Berry, L.L. (1988). SERVQUAL: a multiple item scale for measuring consumer perceptions of service quality. Journal of Retailing,34(1).pp.12-40.

Parasuraman, Berry \& Zeithaml. (1994). Alter-native Scales for Measuring Service Quality: A Comparative Assessment Based on Psych- ometric and Diagnostic Criteria. Journal of Retailing. 70 (3). pp.201-230.

Parasuraman,Berry,\& Zeithaml(1991). Refine-ment and Reassessment. of the SERVQ UAL scale. Journal of Retailing, 67(4),pp. 420-450.

Rod, M., Ashill, N. J., Shao,J \&Carruthers, J. (2009). An examination of the relationship between service quality dimensions, overall internet 
banking service quality and customer satisfaction: A New Zealand study. Marketing Intelligence \& Planning. 27(1).pp.103-126.

Sureshchandar, G. S., Rajendran, C., \& Anantharaman, R. N. (2002). The Relationship between Service Quality and Customer Satisfaction-A Factor Specific Approach. Journal of Services Marketing, 16, pp.363-379.

Wang, I.M \& Shieh, C.J(2006). The relationship between service quality and customer satisfaction: the example of CJCU library. Journal of Information and Optimiz- ation Sciences. 27(1).pp.193-209.
Zaim, H., Bayyurt, N., \& Zaim, S. (2010). Service Quality And Determinants Of Customer Satisfaction In Hospitals: Turkish Experience. International Business \& Econo- mics Research Journal (IBER), 9(5). pp.51-58. 